Magnus Oskarsson PhD in Science Education at the Department of Science Education and Mathematics, Mid Sweden University, Sweden. His research is around students' interest and motivation. He was responsible for Science in TIMSS 2011 and 2015 in Sweden and Swedish National Project Manager for PISA 2015.

Nina Eliasson is a PhD student in Science Education at the Department of Science Education and Mathematics, Mid Sweden University, Sweden. Her main study interests include gender differences in science education.

Karl Göran Karlsson, Professor of Physics Education at the Department of Science Education and Mathematics, Mid Sweden University, Sweden. His research is mainly based on large scale international studies and with special focus on equity.

\title{
MAGNUS OSKARSSON
}

Department of Science Education and Mathematics, Mid Sweden University, Sweden magnus.oskarsson@miun.se

\section{NINA ELIASSON}

Department of Science Education and Mathematics, Mid Sweden University, Sweden nina.eliasson@miun.se

\section{KARL GÖRAN KARLSSON}

Department of Science Education and Mathematics, Mid Sweden University, Sweden kg.karlsson@miun.se

\section{Verkliga vardagssammanhang i årskurs 4 eller kontextlös kunskap i årskurs 8?}

\begin{abstract}
International comparisons of students' knowledge as TIMSS and PISA have shown that Swedish students' knowledge of science deteriorated during the 2000s, compared to both previous years and to other countries. In grade 4, however, the results improved between 2007 and 2011 and Sweden is one of the countries showing the greatest difference between the results in grade 4 and grade 8 , suggesting a weak knowledge development in science between these grades.
\end{abstract}

This study compares Swedish pupils' results for individual tasks in Science in TIMSS 2011 with an average score of countries in the EU or OECD. The items are classified by whether they are put in a context and if they ask for school specific knowledge or if they could be solved with knowledge from sources outside school. A large proportion of the items in grade 4 is linked to a context and to students' everyday lives, which explains the good results for the younger students. Few items in grade 8 are of interest for the students or linked to students' daily lives and on these items Swedish students often perform below average for the EU / OECD, which contributes to the less favorable outcome in grade 8. The weak development of knowledge between grades 4 and 8 that is indicated by TIMSS suggests that the formalized science classes in school do not reach the students and it points to the need for a clearer connection to students' interests and experiences.

\section{BAKGRUND}

Under 2000-talet har flera internationella studier visat att svenska elevers kunskapsnivå sjunkit jämfört med tidigare år och jämfört med andra länder. I PISA (Programme for International Student Assessment) 2012 hade svenska femtonåringar för första gången lägre resultat än medelvärdet 
i OECD inom de tre områden som undersöktes, alltså matematik, naturvetenskap och läsförståelse (OECD, 2014). Även i TIMSS (Trends in International Mathematics and Science Study) 2011 hamnar Sverige för första gången under medelvärdet för EU/OECD i naturvetenskap för årskurs 8. I årskurs 4 låg däremot resultaten i naturvetenskap över medelvärdet för jämförelseländerna, vilket var en förbättring jämfört med TIMSS 2007. Sverige är ett av de länder som visar störst skillnad mellan resultaten i årskurs 4 och i årskurs 8, vilket tyder på en svag kunskapsutveckling i naturvetenskap mellan dessa årskurser (Skolverket, 2012).

Tidigare försök att förklara resultatskillnaderna mellan årskurserna har inte gett några tydliga resultat. Undervisningen i NO fram till årskurs 4 har exempelvis ansetts försummad med brist på såväl material som utbildade NO-lärare. Samtidigt visade TIMSS 2011 att svenska NO-lärare i årskurs 8 både var välutbildade och hade lång erfarenhet jämfört med lärare i många andra länder som deltog i undersökningen. TIMSS ramverk anpassas till de deltagande ländernas kursplaner i så stor utsträckning som möjligt, och vid tidigare analyser av TIMSS-provet verkade både ramverket och provfrågorna matcha de svenska kursplanerna bra och dessutom bättre i årskurs 8 än i årskurs 4 (Skolverket, 2006, 2008b). Frågorna i TIMSS kan delas upp efter ämne: biologi, fysik kemi och geovetenskap, eller efter vilken kognitiv förmåga de avser att mäta: veta, resonera eller tillämpa. Kunskapsprofilerna i de bägge årskurserna var likartade och då fördelningen av frågor mellan områden inte skiljer i någon större utsträckning bidrar varken ämnesområden eller förmågor till förståelsen av resultatskillnaderna mellan årskurserna (Skolverket, 2012). Inte heller ger skillnader i frågeformat någon vägledning. TIMSS-provet består av en blandning av flervalsfrågor och öppnasvarsfrågor men det gäller i ungefär samma utsträckning för bägge årkurserna (Martin, Mullis, Foy, \& Stanco, 2012).

I slutbetygen för årskurs 9 är matematik, biologi, fysik och kemi de ämnen som har lägst betygsmedelvärden (Skolverket, 2016). Resultaten i TIMSS är en indikation på de problem som dessa ämnen har i grundskolans senare del.

Den fråga som ställs i denna artikel är om andra mönster går att hitta i elevsvaren i TIMSS 2011 som kan sprida ljus över resultatskillnaden mellan årskurs 4 och årskurs 8. Vi kommer att undersöka vilken betydelse det har om uppgifterna är i ett för eleverna välkänt sammanhang och om det är skolspecifik kunskap som efterfrågas eller om det är kunskap som eleverna sannolikt inhämtat utanför skolan. I årskurs 8 klassificeras dessutom uppgifterna efter hur intressanta de bedöms vara för eleverna.

\section{Sammanhang}

En faktor som bedömts vara viktig för att kunna lösa en uppgift är i vilken utsträckning den efterfrågar kunskaper som finns i ett för eleven känt sammanhang. En av målsättningarna med skolans undervisning i NO är att göra världen begriplig, ett syfte som finns både i äldre kursplan (Lpo 94 som eleverna i TIMSS 2011 läst efter) och i de nya kursplanerna från 2011 (Skolverket, 2008a, 2011). Samtidigt visar studier att NO-ämnena tillhör de ämnen som framstår som mest skolspecifika där elever i årskurs 9 i nationella utvärderingar av grundskolan rankade fysik och kemi som de ämnen de lärt sig minst om utanför skolan (Skolverket, 2004). Att knyta NO-undervisningen till elevernas vardag och göra undervisningen mer autentisk är ett brett forskningsfält inom naturvetenskapernas didaktik (Nilsson, 2012). Flera studier visar att elever gynnas av att frågeställningar placeras i ett verkligt sammanhang och att det gör det lättare för eleven att visualisera problemen (Benckert, Petterson, Aasa, Johansson, \& Norman, 2012; Rennie \& Parker, 1996). Samtidigt kan ett sammanhang med mycket information och text göra det svårare att identifiera det problem som ska lösas, speciellt om uppgiften avviker från den typ av uppgifter eller problem som eleverna är vana att möta (Park \& Lee, 2004). En stor textmängd kan också i sig utgöra ett hinder, särskilt för lässvaga elever. I TIMSS har dock textmängden tidigare bedömts som förhållandevis liten (Skolverket, 2006, 2008b).

I den gemensamma kursplanen för NO-ämnena i Lpo 94 står det under rubriken Ämnenas syfte och roll $i$ utbildningen att "Naturvetenskapen har vuxit fram ur människans behov av att finna svar 
på de frågor som rör den egna existensen, livet och livsformerna, platsen i naturen och universum." (Skolverket, 2000, s. 50). Det innebär att NO-undervisning bör behandla sådana frågor som har en anknytning till vardagen i vid mening. Olika studier visar dock att NO-undervisningen ofta varken är vardagsanknuten eller knuten till den naturvetenskapliga verksamheten och Andrée (2007) liknar NO-undervisningen vid en slags hybridpraktik med en egen logik som blandar vardagsresonemang och naturvetenskapliga förklaringar.

TIMSS ramverk anger inte i vilken omfattning frågeställningar i uppgifter ska beskrivas utifrån ett sammanhang. Även om det i ramverket för de kognitiva områdena resonera och tillämpa anges att frågeställningar bör vara satta i ett sammanhang, har en tidigare studie visat att upp till 78 procent av uppgifterna i TIMSS 2003 helt saknar sammanhang (Skolverket, 2006). Redan efter TIMSS 1995 fördes en diskussion om att frågorna var för skolspecifika och saknade autentisk kontext (Orpwood, 1998). Den nivåindelning av uppgifter efter sammanhang som görs i denna rapport liknar den som genomfördes efter TIMSS 2003 och vi återkommer till om kontextualisering av uppgifter ökat i TIMSS 2011.

\section{Vardagskunskap}

En annan viktig faktor bakom goda resultat kan vara om frågeställningen kan besvaras med kunskaper som eleven fătt utanför skolan eller om det är frågeställningar eleven endast mött i skolan.

Vardagsaspekten har också att göra med hur en uppgift formuleras eller vilka svar som bedöms som korrekta. Det kan räcka med vardagskunskap för att besvara uppgiften om varken frågan eller det svar som godkänns innehåller specifika naturvetenskapliga termer eller förklaringar (Säljö, 1998). Redan i samband med TIMSS 1995 konstaterades att svenska elever presterade relativt sett bättre resultat på uppgifter som behandlade vardagskunskap (Skolverket, 1996).

Vardagskunskap handlar inte här primärt om huruvida uppgiften har en anknytning till vardagen även om det ofta hänger samman. Att en uppgift kan besvaras med hjälp av vardagskunskap betyder här att de kunskaper som krävs sannolikt kan ha förvärvats utanför skolan, före skolstart eller att de bygger på "sunt förnuft". I rapporten för TIMSS 2011 (Skolverket 2012) redovisas att 97 procent av de svenska eleverna gått i förskola och flera studier visar att den allsidiga verksamhet förskolan bedriver är gynnsam för elevernas lärande senare i skolan (Hattie, 2008; OECD, 2011).

\section{Intresse}

TIMSS har visat att elever i årskurs 4 är mer positiva till NO än elever i årskurs 8 (Skolverket, 2012). Vilket innehåll som intresserar eleverna kan också skilja mellan årskurserna och Jidesjö (2008) har visat att både femte- och niondeklassare är intresserade av rymden och hälsofrågor men att femteklassarna är mer intresserade av frågor om ny teknik och om djur i olika delar av världen. Tidigare forskning har visat att svenska elever har ett lågt intresse för den naturvetenskap som behandlas i grundskolans senare del (Jidesjö, 2012; Lindahl, 2003; Oskarsson, 2011). Teknikdelegationen (2010) beskriver ett sjunkande intresse för naturvetenskap och matematik bland ungdomar med negativa konsekvenser för bland annat rekrytering till naturvetenskapliga och tekniska utbildningar och yrken. Situationen är likartad i många länder inom EU/OECD och frågan kring intresse och rekrytering är därför i fokus i många diskussioner (Henriksen, Dillon, \& Ryder, 2014; Osborne \& Dillon, 2010; Osborne, Simon, \& Collins, 2003; Sjøberg, 2010). Schreiner (2005) pekar på vikten av att ta hänsyn till olika länders sjunkande intresse för naturvetenskap när nationella och internationella resultat ska jämföras. ROSE-studien (Relevance of Science Education) visade exempelvis att elever i de mest utvecklade länderna, som de nordiska, visade lägre intresse för naturvetenskap än elever i många andra länder (Sjøberg \& Schreiner, 2010). De flesta diskussioner och olika studier pekar på betydelsen av att öka intresset för naturvetenskap bland ungdomarna för att på så sätt förbättra resultaten och öka rekryteringen till naturvetenskapliga utbildningar. 
Samtidigt är det viktigt att påpeka att sambandet mellan intresse och resultat mellan länder inte alltid korrelerar på ett förväntat sätt. I PISA 2006 hade exempelvis Finland de bästa resultaten samtidigt som finska elever hade det lägsta intresset för naturvetenskap av alla deltagande länder (Skolverket, 2007). Inom länder finns dock ofta ett positivt samband mellan intresse och resultat. I TIMSS 2011 uppvisar Sverige för årskurs 8 ett positivt samband mellan elevernas inställning till ämnet och deras resultat. I årskurs 4 är det sambandet inte lika tydligt om hänsyn tas till andra bakgrundsfaktorer som social bakgrund och kön. Även i årskurs 8 är sambandet mellan intresse och resultat svagare än för faktorer som självförtroende och social bakgrund (Skolverket, 2012).

Oskarsson (2011) har visat att det inte räcker med att uppgifter är i ett sammanhang för att eleverna skall uppleva att det är intressant utan att det avgörande är om själva grundfrågeställningen upplevs relevant och intressant för eleven. Frågor om exempelvis ljud och ljus väcker inget nämnvärt intresse hos femtonåringar även om de presenteras i sammanhang som handlar om musikinstrument och regnbågar. Inom alla ämnesområden i naturvetenskap finns både intressanta och ointressanta frågeställningar. Frågeställningar som har mer personlig betydelse som exempelvis vad man ska äta och hur man ska träna för att må bra, hur man botar allvarliga sjukdomar och epidemier är intressanta för både pojkar och flickor. Frågor om rymden och frågor där vetenskapen inte har färdiga svar väcker också ett intresse bland en stor majoritet av eleverna (Oskarsson, 2011).

\section{SYFTE}

I denna artikel har vi kategoriserat uppgifterna i naturvetenskap i TIMSS 2011 efter sammanhang, vardagskunskap och intresse för att undersöka i vilken utsträckning dessa kan förklara:

- Svenska elevers goda resultat i naturvetenskap TIMSS årskurs 4 där svenska elever visar signifikant bättre resultat än elever i relevanta jämförelseländer.

- Svenska elevers mindre goda resultat i naturvetenskap TIMSS årskurs 8 där svenska elever visar signifikant sämre resultat än elever i relevanta jämförelseländer.

- Den relativt svaga kunskapsutvecklingen för svenska elever i naturvetenskap mellan dessa årskurser

\section{MetOd}

Alla uppgifter i TIMSS 2011 har granskats och kategoriserats utifrån Sammanhang, Vardagskunskap och Intresse (årskurs 8). Två av författarna har oberoende bedömt uppgifterna med avseende på respektive kategori. Överenstämmelsen i den första bedömningen var god och varierade mellan $82 \%$ för sammanhang i årskurs 4 till 93 \% för Intresse i årskurs 8.

Där det funnits olika uppfattningar har den tredje författaren genomfört ytterligare en oberoende bedömning och därefter har en gemensam samlad bedömning genomförts.

I kategorin Sammanhang har uppgifterna delats in i tre olika nivåer och de har definierats enligt följande:

- ett välkänt sammanhang innebär att eleven med stor sannolikhet har upplevt detta själv utanför skolan eller är bekant med situationen från TV eller liknande.

- något sammanhang innebär att det är autentiskt och återfinns utanför klassrummet, men ligger utanför de flesta elevers erfarenheter eller att beskrivningen av sammanhanget är begränsad till stiliserade bilder.

- inget sammanhang innebär att frågan återfinns i en ren skolkontext eller helt saknar sammanhang. Det kan handla om fakta, diagram eller experimentuppställningar.

I kategorin Vardagskunskap har uppgifterna delats in i två nivåer där:

- vardagskunskap innebär att frågan går att besvara med vardagskunskap varmed avses att eleven sannolikt haft möjlighet att lära sig detta utanför skolan eller innan skolstart. Det kan handla 
om vanliga vardagsfenomen eller uppgifter som går att lösa med enkla logiska resonemang eller "sunt förnuft".

- skolspecifik kunskap innebär att frågan kräver kunskap som de allra flesta elever måste inhämta i skolan.

Eftersom TIMSS 2011 visar att intresset för NO är lägre i årskurs 8 än i årskurs 4 skulle det kunna vara en av förklaringarna till de låga resultaten i årskurs 8. Därför studeras i denna rapport speciellt hur intresse påverkar resultaten i den senare årskursen.

I kategorin Intresse har uppgifterna delats in i tre nivåer som bygger på resultat från ROSE-studien (Jidesjö, 2012; Oskarsson, 2011).

- högt intresse handlar om frågor av hög relevans för eleven personligen, som exempelvis hur fysisk träning kan bedrivas eller vad som är bra att äta för en god hälsa. Det kan handla om hur svåra sjukdomar kan botas, om sex samt om droger. Rymden och frågor där vetenskapen inte har färdiga svar är också av stort intresse bland eleverna.

- medelstort intresse kan röra frågor om ny teknik, spektakulära fenomen, nya uppfinningar utan att de behöver vara direkt relevanta för eleverna själva.

- lågt intresse omfattar frågor som ofta handlar om den traditionella naturvetenskapen i skolan. Det kan handla om atomer och molekyler, om ljud och ljus även om dessa kommer från musikinstrument eller syns i regnbågen. Elever visar även lågt intresse för vardagsföreteelser som hur tvål och tvättmedel fungerar eller för växter och djur i närmiljön.

Det förtjänar att påpekas att den indelning av uppgifter som vi gjort skett utifrån en svensk kontext. Vi har bedömt vad som kan vara välkänt, vardagskunskap eller intressant för svenska elever utifrån den kännedom vi har och forskning som finns om exempelvis svenska förskolor, svenska medier, svenskt vardagsliv och intressen hos svenska elever. I en globaliserad värld möter dock barn och ungdomar i de länder som Sverige jämförs med samma eller liknande kulturyttringar. Schreiner \& Sjøberg (2010) visar också att elever i andra länder inom EU/OECD i stor utsträckning är intresserade av samma områden som de svenska eleverna.

De resultat som presenteras här har beräknats på uppgiftsnivå utifrån andelen korrekta svar på TIMSS-uppgifterna 2011 för Sverige och EU/OECD. I provet för årskurs 4 fanns 168 naturvetenskapliga uppgifter och för årskurs 8 fanns 214 uppgifter. Samtliga dessa uppgifter har analyserats. Hälften av uppgifterna är frisläppta av IEA och finns tillgängliga med resultatredovisningar (Skolverket, 2014a, 2014b). Resultaten på ej frisläppta uppgifter har tagits fram av författarna. Analyser har genomförts för de kategorier som enligt tidigare beskrivning bedömts som särskilt intressanta att studera vidare, det vill säga Sammanhang, Vardagskunskap och för årskurs 8 även Intresse.

\section{Signifikans}

I rapporten jämförs antalet uppgifter där Sverige har signifikant bättre eller sämre resultat inom respektive kategori. Förhållandet är inte linjärt mellan andelen korrekta svar för ett land och de TIMSS-poäng som redovisats i TIMSS-rapporten 2011 (Skolverket, 2012) utan ländernas TIMSSpoäng beräknas både utifrån antalet lösta uppgifter och efter svårighetsgraden på dessa uppgifter. Svårighetsgraden för en uppgift avgörs av den genomsnittliga lösningsfrekvensen vid det tillfälle då uppgiften användes för första gången (Martin \& Mullis, 2014). En lätt uppgift har alltså hög andel korrekta svar och en svår uppgift en låg andel.

På uppgiftsnivå finns resultat och medelfel för frisläppta uppgifter presenterade men inte för de uppgifter som omfattas av sekretess inför kommande TIMSS-cykler. De medelfel som hör till de ej frisläppta uppgifterna har uppskattats utifrån de kända medelfelen för de frisläppta uppgifterna. Medelfelet i andelen korrekta svar på dessa uppgifter varierar för Sverige mellan o,8 och 2,4 procentenheter och mellan 0,2 och 0,3 procentenheter för det internationella medelvärdena. Det innebär att det kombinerade felet som uppstår vid en jämförelse av resultat mellan Sverige och EU/OECD som 
mest kommer att uppgå till 2,5 procentenheter. Ett medelfel på 2,5 har därför antagits för samtliga uppgifter för att med god marginal säkerställa att en skillnad i resultat på mer än fem procentenheter är signifikant på $5 \%$ nivå.

\section{Regression}

Det är troligt att de nya kategorierna har ett visst mått av samvariation och en uppgift som går att lösa med vardagskunskaper kan mycket väl finnas i ett intressant sammanhang och vad som påverkar resultatet mest syns inte vid en första analys. För att separera inverkan av de använda kategorierna genomförs en multipel linjär regression med resultatskillnaden i andel korrekta svar på varje uppgift mellan Sverige och EU/OECD som beroende variabel och de nya kategorierna, Vardagskunskap, Sammanhang och Intresse som oberoende variabler.

Vi har använt en enkel linjär regressionsmodell och kodat de olika kategorierna som 1 och 2 respektive 1, 2 och 3. Vi behandlar dessa som intervallskalor fast de egentligen är ordinala, och bedömer att metoden trots denna reservation ger tillräckligt tillförlitliga resultat.

\section{RESULTAT}

I detta avsnitt presenteras resultat på uppgiftnivå i TIMSS 2011 för Sverige jämfört med EU/OECD uppdelat på de nya kategorierna. Vi börjar med årskurs 4 och sedan följer årskurs 8.

\section{Årskurs 4}

I årskurs 4 har 168 uppgifter analyserats och för 58 av dessa är resultatet signifikant högre i Sverige än i EU/OECD och för 27 är det lägre. Andelen korrekt lösta uppgifter är i Sverige 55,5 procent jämfört med 53 procent i EU/OECD. Detta kan jämföras med TIMSS-resultatet som var 533 poäng i Sverige mot 520 i EU/OECD. Även om förhållandet mellan andel korrekta svar och TIMSS-poängen inte är linjärt, enligt tidigare beskrivning, ger detta ändå en uppfattning om förhållandet mellan dessa. I årskurs 4 har uppgifterna kategoriserats efter sammanhang och vardagskunskap enligt tidigare beskrivning.

\section{Sammanhang i årskurs 4}

Tabell 1 visar alla uppgifter fördelade efter de tre nivåer av sammanhang och om Sverige presterar signifikant bättre respektive sämre efter dessa i förhållande till genomsnittet i EU/OECD.

Tabell 1 Antal uppgifter $i$ årskurs 4 fördelade på Sammanhang med antal korrekta svar över respektive under EU/OECD-genomsnitt.

\begin{tabular}{|l|c|c|c|c|}
\hline & Över EU/OECD & $\begin{array}{c}\text { Ej skilt från EU/ } \\
\text { OECD }\end{array}$ & Under EU/OECD & Summa \\
\hline välkänt sammanhang & 16 & 17 & 0 & 33 \\
\hline något sammanhang & 31 & 34 & 12 & 77 \\
\hline inget sammanhang & 11 & 32 & 15 & 58 \\
\hline S:a & 58 & 83 & 27 & 168 \\
\hline
\end{tabular}

Det svenska resultatet ligger inte under medelresultatet i EU/OECD på någon uppgift med ett välkänt sammanhang, men även på uppgifter med något sammanhang lyckas svenska elever bra. Uppgifter med inget sammanhang är uppenbarligen mer problematiska för svenska elever. 


\section{Vardagskunskap i årskurs 4}

Uppgifterna har bedömts efter en tvågradig skala beroende på om de anses kunna lösas med vardagskunskaper eller om det är skolspecifik kunskap.

Tabell 2 Antal uppgifter $i$ årskurs 4 fördelade på vardagskunskap och skolspecifik kunskap med antal korrekta svar över respektive under EU/OECD-genomsnitt.

\begin{tabular}{|l|c|c|c|c|}
\hline & Över EU/OECD & $\begin{array}{c}\text { Ej skilt från EU/ } \\
\text { OECD }\end{array}$ & $\begin{array}{c}\text { Under EU/ } \\
\text { OECD }\end{array}$ & summa \\
\hline vardagskunskap & 36 & 31 & 3 & 70 \\
\hline skolspecifik kunskap & 22 & 52 & 24 & 98 \\
\hline summa & 58 & 83 & 27 & 168 \\
\hline
\end{tabular}

Som framgår av tabell 2 är uppgifter där det räcker med vardagskunskap till klar fördel för svenska elever medan lösningsfrekvensen på uppgifter som inte handlar om vardagskunskap inte avviker från medlet i EU/OECD.

\section{Vad påverkar resultatet i årskurs 4}

Det finns en viss samvariation mellan sammanhang och vardagskunskap. Tabell 3 visar fördelningen av antalet uppgifter i provet för årskurs 4 utifrån de nya kategorierna.

Tabell 3 Fördelning av uppgifter i naturvetenskap, årskurs 4

\begin{tabular}{|l|c|c|c|}
\hline & vardagskunskap & $\begin{array}{c}\text { Skolspecifik } \\
\text { kunskap }\end{array}$ & summa \\
\hline välkänt sammanhang & 26 & 7 & 33 \\
\hline något sammanhang & 30 & 47 & 77 \\
\hline inget sammanhang & 14 & 44 & 58 \\
\hline summa & 70 & 98 & 168 \\
\hline
\end{tabular}

En betydligt större andel av uppgifter med ett välkänt sammanhang bedöms kunna lösas med vardagskunskap jämfört med uppgifter med inget sammanhang. Men det finns också uppgifter som bedömts som inget sammanhang som kan lösas med vardagskunskaper liksom uppgifter som kategoriserats välkänt sammanhang men där vardagskunskaper inte räcker för att besvara uppgiften korrekt.

Såväl vardagskunskap som sammanhang bidrar till goda resultat för svenska elever. Av de 168 uppgifter i årskurs 4 som analyserats ligger Sverige över medel i andel korrekta svar på 58 uppgifter och av dessa har 50 uppgifter minst något sammanhang och/eller är vardagskunskap.

För att avgöra vilken av dessa kategorier som påverkar resultatet mest genomförs en multipel regressionsanalys där de enskilda kategoriernas inverkan kan särskiljas. 
Tabell 4 Regressionsmodell med Sammanhang, Vardagskunskap mot skillnad i genomsnittlig andel korrekta svar mellan Sverige och EU/OECD i naturvetenskap, årskurs 4

\begin{tabular}{|l|l|l|}
\hline $\mathbf{r}=\mathbf{0 , 4 1 3}$ & $\mathrm{K}$ & $\mathrm{P}$ \\
\hline Konstant & $-1,859$ & \\
\hline Sammanhang & 2,712 & 0,004 \\
\hline Vardagskunskap & 4,806 & $<0,001$ \\
\hline
\end{tabular}

Både Sammanhang och Vardagskunskap är signifikanta i modellen och ger ett positivt bidrag till Sveriges resultat. Den genomsnittliga skillnaden mellan inget sammanhang och välkänt sammanhang är enligt modellen $2^{*} 2,7=5,4$ procentenheter kontrollerat för hur vardagskunskaper påverkar resultatet. På samma sätt ger uppgifter med vardagskunskaper en förbättring av resultatet med 4,8 procentenheter jämfört med EU/OECD.

På samma sätt blir skillnaden mellan Sverige och EU/OECD för en uppgift med både vardagskunskaper och ett välkänt sammanhang $-1,859+2^{*} 2,7+4,8=8,4$ procentenheter Svenska elever har alltså i genomsnitt 8,4 procentenheter bättre resultat på en uppgift i årskurs 4 med ett välkänt sammanhang och som kan lösas med vardagskunskaper jämfört med elever i EU/OECD.

\section{Årskurs 8}

I årskurs 8 har 214 uppgifter analyserats och på 41 av dessa har Sverige bättre resultat än EU/OECD och på 72 är resultatet lägre. I Sverige är genomsnitt andel korrekta svar 47,5 procent mot 49 procent i EU/OECD. Det kan jämföras med TIMSS-poängen som är 509 i Sverige och 516 i EU/OECD.

I årkurs 8 finns alltså betydligt fler uppgifter där de svenska resultaten ligger under det internationella medelvärdet och färre där resultatet ligger över medel jämfört med årskurs 4. På samma sätt som i årskurs 4 är frågan vad som karaktäriserar uppgifter där svenska elever presterar väl. I årskurs 8 har samma kategorier använts som i årskurs 4, alltså Sammanhang och Vardagskunskap. Dessutom har uppgifterna bedömts efter om de anses vara intressanta för eleverna.

\section{Sammanhang i årskurs 8}

Det är färre uppgifter med ett välkänt sammanhang i årskurs 8 än i årskurs 4. Tabell 5 visar fördelningen mellan uppgifter med avseende på sammanhang.

Tabell 5 Antal uppgifter $i$ årskurs 8 fördelade på Sammanhang med antal korrekta svar över respektive under EU/OECD-genomsnitt.

\begin{tabular}{|l|c|c|c|c|}
\hline & $\begin{array}{c}\text { Över EU/ } \\
\text { OECD }\end{array}$ & $\begin{array}{c}\text { Ej skilt från EU/ } \\
\text { OECD }\end{array}$ & $\begin{array}{c}\text { Under EU/ } \\
\text { OECD }\end{array}$ & summa \\
\hline välkänt sammanhang & 5 & 7 & 3 & 15 \\
\hline något sammanhang & 24 & 52 & 28 & 104 \\
\hline inget sammanhang & 12 & 42 & 41 & 95 \\
\hline summa & 41 & 101 & 72 & 214 \\
\hline
\end{tabular}


Det är värt att notera att 119 av 214 uppgifter (56 \%) har bedömts ha åtminstone något sammanhang. Majoriteten av uppgifterna där de svenska resultaten ligger över EU/OECD-medelvärdet har åtminstone något sammanhang och uppgifterna med resultat under medelvärdet har ofta inget sammanhang. Det är få uppgifter som har ett välkänt sammanhang utan sammanhangen finns ofta utanför elevernas egna erfarenheter.

\section{Vardagskunskap i årskurs 8}

Uppgifterna som bedöms kunna besvaras med vardagskunskap är tämligen sällsynta i årskurs 8. Bara 26 uppgifter är klassificerade som vardagskunskap medan 188 är skolspecifik kunskap.

Tabell 6 Antal uppgifter i årskurs 8 fördelade på vardagskunskap och skolspecifik kunskap med antal korrekta svar över respektive under EU/OECD-genomsnitt.

\begin{tabular}{|l|c|c|c|c|}
\hline & $\begin{array}{c}\text { Över EU/ } \\
\text { OECD }\end{array}$ & $\begin{array}{c}\text { Ej skilt från EU/ } \\
\text { OECD }\end{array}$ & $\begin{array}{c}\text { Under EU/ } \\
\text { OECD }\end{array}$ & summa \\
\hline vardagskunskap & 12 & 12 & 2 & 26 \\
\hline Skolspecifik kunskap & 29 & 89 & 70 & 188 \\
\hline summa & 41 & 101 & 72 & 214 \\
\hline
\end{tabular}

Av de 26 uppgifter som bedöms kunna lösas med vardagskunskap finns endast två där Sveriges resultat ligger under EU/OECD-medelvärdet. Av de skolspecifika uppgifterna är mer än dubbelt så många under som över medel.

\section{Intresse i årskurs 8}

Alla uppgifter för årskurs 8 har också delats upp efter om de bedöms vara intressanta för eleverna.

Tabell 7 Antal uppgifter i årskurs 8 fördelade på Intresse med antal korrekta svar över respektive under EU/OECD-genomsnittet.

\begin{tabular}{|l|c|c|c|c|}
\hline & $\begin{array}{c}\text { Över EU/ } \\
\text { OECD }\end{array}$ & $\begin{array}{c}\text { Ej skilt från EU/ } \\
\text { OECD }\end{array}$ & $\begin{array}{c}\text { Under EU/ } \\
\text { OECD }\end{array}$ & summa \\
\hline högt intresse & 5 & 3 & 0 & 8 \\
\hline medelstort intresse & 18 & 32 & 7 & 57 \\
\hline lågt intresse & 18 & 66 & 65 & 169 \\
\hline summa & 41 & 101 & 72 & 215 \\
\hline
\end{tabular}

Det är stora skillnader i svenska elevers resultat beroende på hur intressanta uppgifterna bedöms vara. Av de uppgifter som bedömts vara av högt eller medelstort intresse har svenska elever lägre resultat än EU/OECD på endast sju uppgifter av 65. Bland uppgifter som bedömts ha lågt intresse är det svenska resultatet under medelvärdet i EU/OECD på 65 av 149 uppgifter. 
Det är bara är åtta uppgifter som bedöms vara riktigt intressanta för eleverna i årskurs 8 och det är tydliga skillnader mellan dessa och övriga uppgifter. Även för medelintressanta uppgifter är de svenska resultaten väsentligt bättre än för uppgifter med lågt intresse.

\section{Vad påverkar resultatet i årskurs 8}

Vilken av kategorierna har störst inverkan på resultatet? Tabell 8 visar en sammanställning av hur uppgifterna i årskurs 8 har kategoriserats

Tabell 8 Kategorisering av uppgifter i naturvetenskap årskurs 8. Sammanhang, Intresse och Vardagskunskap.

\begin{tabular}{|l|c|c|c|c|c|c|c|c|}
\hline & \multicolumn{2}{|c|}{ högt intresse } & \multicolumn{2}{c|}{$\begin{array}{c}\text { medelstort } \\
\text { intresse }\end{array}$} & \multicolumn{2}{|c|}{ lågt intresse } & \multicolumn{2}{|c|}{ summa } \\
\hline vardag & $\begin{array}{c}\text { skol- } \\
\text { specifik }\end{array}$ & vardag & $\begin{array}{c}\text { skol- } \\
\text { specifik }\end{array}$ & vardag & $\begin{array}{c}\text { skol- } \\
\text { specifik }\end{array}$ & vardag & $\begin{array}{c}\text { skol- } \\
\text { specifik }\end{array}$ \\
\hline $\begin{array}{l}\text { välkänt } \\
\text { samman- } \\
\text { hang }\end{array}$ & 3 & 1 & 2 & 4 & 1 & 4 & 6 & 9 \\
\hline $\begin{array}{l}\text { något } \\
\text { samman- } \\
\text { hang }\end{array}$ & 2 & 2 & 10 & 33 & 6 & 51 & 18 & 86 \\
\hline $\begin{array}{l}\text { inget } \\
\text { samman- } \\
\text { hang }\end{array}$ & 0 & 0 & 1 & 7 & 1 & 86 & 2 & 93 \\
\hline summa & 5 & 3 & 13 & 44 & 8 & 141 & 26 & 188 \\
\hline
\end{tabular}

Alla undersökta variabler, Sammanhang, Vardagskunskap, och Intresse verkar påverka hur svenska elever lyckas i TIMSS 2011. Men flera av dessa variabler samvarierar enligt tabell 8 och nästan alla uppgifter med inget sammanhang bedöms exempelvis också vara lågt intresse. Korrelationen mellan Sammanhang och Intresse är 0,46 och för att studera vilka av dessa som påverkar resultatet genomförs precis som för årskurs 4 en multipel regressionsanalys.

Tabell 9 Regressionsmodell med Sammanhang, Vardagskunskap och Intresse

\begin{tabular}{|l|l|l|}
\hline $\mathbf{r}=0,437$ & $\mathrm{~K}$ & $\mathbf{P}$ \\
\hline Konstant & $-3,851$ & \\
\hline Sammanhang, & 0,42 & 0,65 \\
\hline Vardagskunskap & 5,32 & 0,002 \\
\hline Intresse & 4,17 & $<0,001$ \\
\hline
\end{tabular}

Av modellen framgår att Intresse och Vardagskunskap är de avgörande variablerna och att Sammanhang inte blir signifikant i en gemensam modell. Inte heller i en modell med dikotoma variabler blir något sammanhang eller välkänt sammanhang signifikanta. Den höga korrelationen mellan Intresse och Sammanhang kan försvåra tolkningen men vid en kontroll av multikollinearitet visar att koefficienterna kan betraktas som stabila. 
En ny modell med bara Vardagskunskap och Intresse blir då

Tabell 10 Regressionsmodell med Vardagskunskap och Intresse

\begin{tabular}{|l|l|l|}
\hline $\mathbf{r}=\mathbf{0 , 4 3 2}$ & $\mathbf{K}$ & $\mathbf{P}$ \\
\hline Konstant & $-3,67$ & \\
\hline Vardagskunskap & 5,46 & 0,001 \\
\hline Intresse & 4,36 & $<0,001$ \\
\hline
\end{tabular}

Koefficienterna säger att på uppgifter med vardagskunskap är skillnaden mellan Sverige och OECD nästan 5,5 procentenheter till Sveriges fördel om vi jämför uppgifter med skolspecifik kunskap rensat för det bidrag till resultatskillnaden som Intresse ger.

På samma sätt ger Intresse ensamt koefficienten 4,36 vilket motsvarar 8,7 procentenhets skillnad mellan inget intresse och högt intresse. En uppgift med högt intresse och vardagskunskap, kommer att ha mer än tio procentenheter högre andel korrekta svar i Sverige än i EU/OECD.

\section{DisKussion}

Syftet med denna artikel var att söka förklaringar till svenska elevers goda resultat i TIMSS 2011 årskurs 4, de mindre goda resultaten i årskurs 8 och den svaga kunskapsutvecklingen mellan dessa årskurser.

I TIMSS-rapporten 2011 beskrevs olika undervisningsfaktorer och hur de samvarierar med resultatet (Skolverket, 2012). Att elevernas inställning till naturvetenskap är mindre positiv i årskurs 8 än i årskurs 4 var ett tydligt resultat, men samtidigt var detta inte unikt för Sverige utan det gällde även för många av jämförelseländerna. Även elevernas självförtroende var lägre i årskurs 8 än i årskurs 4, men inte heller denna skillnad var unik för svenska elever. Skillnader i inställning eller självförtroende gav alltså inte någon direkt vägledning till att förstå de relativt sämre kunskaperna i årskurs 8 i Sverige i förhållande till jämförelseländerna. Vi ska återkomma till olika bakgrunds- och undervisningsfaktorer senare.

Denna artikel bygger på de i någon mening mest grundläggande resultaten från TIMSS-undersökningen, nämligen hur eleverna faktiskt lyckas svara på olika typer av frågor i provet. Uppgifterna i TIMSS delas in i olika innehållsliga och kognitiva områden men resultaten visar att det är svårt att utifrån denna indelning se några skillnader mellan årskurs 4 och årskurs 8 som skulle kunna sprida ljus över de lägre resultaten i årskurs 8. TIMSS-frågorna ryms i huvudsak inom de svenska kursplanerna och överensstämmelsen är något högre i årskurs 8 än årskurs 4 och i bägge årskurserna är överensstämmelsen högre än för genomsnittet av jämförelseländer. Det finns därför ingen anledning att tro att bristande överensstämmelse med kursplanerna kan förklara resultatskillnaden mellan årskurserna.

Vi har, med stöd i forskning, argumenterat för att andra indelningar av uppgifter kanske kan förklara resultaten, exempelvis om uppgifterna knyts till sammanhang som är välkända för eleverna eller om de kan lösas med kunskaper eleven fătt i sin vardag. Vi har också prövat om uppgifter som rör områden som elever i andra studier upplevt som intressanta ger bättre resultat. Hur välkänt ett sammanhang är, om en uppgift bygger på vardagskunskap eller om den är intressant avser bedömningar utifrån svenska förhållanden, men jämförelseländerna inom EU/OECD är länder som på många sätt liknar Sverige. I en allt mer globaliserad värld är också ungdomskulturen allt mer gemensam och elevers attityder och intresseområden är likartade om man jämför elever i länder som liknar varandra 
(Sjøberg \& Schreiner, 2010).

\section{Årskurs 4}

Som tidigare konstaterats har de svenska resultaten i naturvetenskap årskurs 4 förbättrats mellan 2007 och 2011, mycket beroende på att resultaten i fysik och kemi förbättrats. I årskurs 4 finns fler än dubbelt så många uppgifter där Sveriges resultat ligger över medelvärdet i EU/OECD jämfört med det antal uppgifter där Sveriges resultat ligger under medelvärdet. Resultaten visar att svenska elever presterar jämförelsevis bättre om uppgifterna går att lösa med vardagskunskap eller om problemet i uppgiften presenteras i ett sammanhang. Regressionsmodellen visade att Svenska elever hade 8,5 procentenheter högre andel korrekta svar på uppgifter i ett sammanhang som går att lösa med vardagskunskaper vilket kan jämföras med Sveriges resultat som var 13 TIMSS-poäng respektive 2,5 procentenheter andel korrekta svar över medel i EU/OECD. En skillnad på 8,5 procentenheter skulle då motsvara över 40 TIMSS-poäng vilket är skillnaden mellan Sverige och länder med allra högst resultat i TIMSS.

Det är knappast förvånande att eleverna gynnas av att en uppgift presenteras i ett välkänt sammanhang, men detta borde även gälla elever i andra länder. Frågan är om inte elever i andra EU/OECDländer, varav många liknar Sverige, borde känna igen ungefär samma sammanhang eller ha ungefär samma vardagskunskap. En möjlig förklaring är att svenska barn och ungdomar i större utsträckning än barn och ungdomar i många andra länder är vana att vistas i skog och mark. I Sverige och i de andra nordiska länderna finns starka traditioner att vistas ute i naturen - att plocka bär och svamp, att bada i sjöar och hav och att fiska (Jidesjö \& Oskarsson, 2016). En överväldigande majoritet av barn i Sverige har gått i förskola, och en viktig del i förskolans verksamhet är uteaktiviteter av olika slag. Många förskolor ägnar sig också åt enkla naturvetenskapliga experiment. Många skolor i Sverige ligger nära naturen och har "naturrutor" eller liknande i skolans närhet. Allt detta ger en viss förtrogenhet med naturfenomen och det skapar också ett intresse för natur i allmänhet. Skolinspektionens granskning av NO-undervisningen i årskurs 1-3 ger också en positiv bild av ämnet där eleverna uppskattar det tillåtande klimatet och att de får göra så mycket (Skolinspektionen, 2012).

Resultaten i denna studie tyder på att elevernas erfarenheter före och utanför skolan kan bidra till de goda resultaten i årkurs 4, och andra studier visar att undervisningen uppskattas av eleverna och att den tycks koppla till deras erfarenheter. Det som vi betecknat som vardagskunskaper blir utslagsgivande men också att eleverna förstår naturvetenskapliga uppgifter som placeras i sammanhang de känner igen. Saknas sammanhang och koppling till elevernas egna erfarenheter syns dock problem redan i årskurs 4 och det pekar mot att undervisningen kring den mer formaliserade naturvetenskapen måste utvecklas.

\section{Årskurs 8}

Resultaten för Sverige i årskurs 8 är som tidigare beskrivits lägre än i årskurs 4. På uppgiftsnivå syns t.ex. i tabell 5 att Sveriges resultat ligger över EU/OECD-genomsnittet på 41 uppgifter och under genomsnittet på 72 uppgifter. Vid en första analys verkar alla tre kategorierna sammanhang, vardagskunskap och om uppgiften är intressant påverka elevernas resultat. Men i en regressionsanalys är endast vardagskunskap och intresse signifikanta. En uppgift med högt intresse och vardagskunskap kommer att ha mer än tio procentenheter högre andel korrekta svar i Sverige än i EU/OECD. Detta kan jämföras med Sveriges resultat i årskurs 8 som var 2,5 procentenheter respektive 7 TIMSS-poäng under medel för EU/OECD.

Resultatet i denna studie visar att sammanhang som inte är intressanta inte ger bättre resultat i årkurs 8. De flesta intressanta uppgifterna i TIMSS finns i ett sammanhang så på många sätt är sammanhang ett nödvändigt, men inte tillräckligt villkor för att väcka intresse och ge goda resultat. Analys av TIMSS 2003 visade att mindre än en fjärdedel av uppgifterna i den undersökningen var satta i ett 
sammanhang (Skolverket, 2006). Den analys som gjorts av TIMSS-uppgifter i denna rapport tyder på att andelen uppgifter i ett sammanhang ökat och är nu över hälften (tabell 5). Detta skulle kunna vara ett resultat av den diskussion som funnits inom IEA om att öka kontextualiseringen av uppgifterna (Orpwood, 1998). Men det ökade antalet uppgifter med ett sammanhang i TIMSS verkar alltså inte ha påverkat resultatet positivt i årskurs 8. Forskning visar att en ökad kontextualisering där problem presenteras i ett sammanhang kan ge olika resultat. Benckert et al. (2012) visade att sammanhang var positivt för elevernas förståelse medan andra studier visar att mycket information och text kan göra det svårare att hitta den fråga som ska besvaras (Park \& Lee, 2004). Oskarsson (2011) visade också att inte alla sammanhang är intressanta för femtonåriga elever. Många av sammanhangen i TIMSS är utanför elevernas egna erfarenheter och bilder och illustrationer är ofta stiliserade utan skala eller bakgrund (Skolverket, 2014b). Att mycket text kan vara problematisk kan också ge en vägledning till de svaga svenska resultaten i PISA, där nästan alla uppgifter är satta i ett sammanhang med en ofta ganska omfattande inledande text som presenterar problemet (Skolverket, 2006, 2013).

Tidigare har beskrivits hur elevernas inställning till NO samvarierar med resultatet på provet men att det inte förklarar så stor del av variationen i resultat. Men på uppgiftsnivå är inverkan stor om uppgiften är intressant. För Intresse har vi använt en tregradig skala och uppgifter med högt respektive lågt intresse ger 8 procentenheters resultatskillnad jämfört med EU/OECD. En uppgift med högt intresse som går att lösa med vardagskunskap ger i genomsnitt 10,5 procentenheter bättre resultat än EU/OECD medan en uppgift som inte uppfyller något av dessa kriterier ger ett resultat som är 3,7 procentenheter lägre än EU/OECD, alltså en skillnad på 14 procentenheter. Intresse verkar alltså vara en avgörande faktor bakom om eleverna lyckas lösa TIMSS-uppgifterna. Här kommer också frågan in om eleverna var motiverade att göra TIMSS-provet. Eklöf (2010) visar hur provresultaten måste ses som en funktion av både kunskap och motivation. Samtidigt visar exempelvis studier av PISA att även om testmotivationen sjunkit är den inte en huvudförklaring till de låga resultaten (Eklöf, 2015).

\section{Den svaga kunskapsutvecklingen mellan årskurs 4 och årskurs 8}

Vi har visat att svenska elever presterar bra på uppgifter som presenteras i välkända sammanhang, som kan lösas med vardagskunskaper och att det i årskurs 8 krävs att sammanhangen är intressanta. De presterar relativt sett bättre på sådana uppgifter än elever i jämförelseländer. De flesta uppgifter i provet för årskurs 8 är varken intressanta eller beskriver något för eleverna välbekant och det blir en vägledning till att förstå de svaga resultaten där. Även om TIMSS inte täcker hela den svenska kursplanen så motsvaras ändå de allra flesta TIMSS-uppgifterna av punkter i det centrala innehållet i kursplanerna och speglar sannolikt betydande delar av innehållet i undervisningen i NO-ämnena på många skolor. Forskning visar också att NO-undervisningen i årskurs 8 precis som TIMSS-uppgifterna tycks ha svag anknytning till sammanhang utanför skolan och svenska lärare uppger exempelvis att de mer sällan anknyter till elevernas vardag än lärare i jämförelseländerna (Skolverket, 2012). Skolinspektionen (2010) beskriver också hur eleverna i årskurs 8 upplever fysikämnet som svårt och enformigt och att de inte ser någon mening med att lära sig det. Läromedlen i fysik har också svag koppling både till samhället i stort och till yrkeslivet (Hedrén \& Jidesjö, 2010). De svaga resultaten i TIMSS för årskurs 8 säger därmed sannolikt något om att undervisningen i NO-ämnena inte når fram till eleverna.

Inställningen till naturvetenskap och intresset för naturvetenskap, och speciellt för den naturvetenskap som bedrivs i skolan, sjunker mellan årskurs 4 och årskurs 8 (Lindahl, 2003). Detta kan bero på att det finns fler konkurrerande intressen för äldre elever, men det verkar också hänga samman med en kollision mellan rådande ungdomskultur och skolkultur, där naturvetenskap av många tonåringar uppfattas som mindre lockande och något som har mycket lite att göra med deras dagliga liv eller deras framtidsdrömmar (Oskarsson, 2011). Det hänger troligen också samman med att NOundervisningen från omkring årskurs 7 ändrar karaktär från en ganska fri undersökande aktivitet till formaliserade ämnen med krav på stringens och att behärska en speciell terminologi och specifika 
rutiner. För många elever kan denna förändring av ämnets innehåll och karaktär innebära både lägre intresse och lägre självförtroende (Lindahl, 2003; Skolverket, 2012).

Det är emellertid inte förvånande att färre uppgifter i årskurs 8 än i årskurs 4 handlar om vardagskunskap i takt med det ökade ämnesinnehållet och mer komplexa problem som eleverna förväntas kunna lösa i årskurs 8. Samtidigt pekar resultaten på att mer behöver göras för att knyta elevernas goda vardagskunskap och kännedom om sammanhang till mer skolspecifik kunskap som TIMSS också efterfrågar. Eleverna i årskurs 8 har rimligtvis mer erfarenheter av olika slag än de yngre eleverna men det är ändå bara knappt hälften så många uppgifter som har ett välkänt sammanhang i årskurs 8 jämfört med i årskurs 4. Det säger något om TIMSS-frågornas svaga anknytning till vardagen utanför skolan framför allt i årskurs 8. Det kan också ge en vägledning till varför sammanhang i TIMSS är en viktigare faktor för de yngre eleverna.

Men precis som med sammanhang och vardagsanknytning bör intresse vara en positiv faktor även i jämförelseländerna. Elevernas intresseområden i tonåren liknar varandra i många av länderna i EU/ OECD (Schreiner, 2005; Sjøberg \& Schreiner, 2010), men resultaten indikerar att elevernas intressen påverkar resultaten mer i Sverige än i jämförelseländerna. En tänkbar förklaring kan vara att ungdomar i Sverige är mer selektiva, kanske mer än ungdomar i en del andra länder. I ett modernt samhälle med ett massivt informationsbrus är det nödvändigt att göra många val och det går inte att ta in all information samtidigt. Svenska ungdomar är självständiga och inte särskilt auktoritetsbundna. I jämförelser som görs av hur värderingar skiljer sig åt mellan olika länder, som exempelvis World Value Survey utmärker sig Sverige som det land där medborgarna tydligast prioriterar livskvalité och självförverkligande (World Value Survey, 2015).

Oskarsson (2011) visar också hur elevernas intresse för olika frågor blir en avgörande faktor för valet av gymnasieprogram, vilket illustrerar att eleverna själva i stor utsträckning gör sina egna livsval. Det är också känt att svenska (och nordiska) ungdomar är bland de allra mest aktiva på sociala medier (OECD, 2013). Detta kan vara en aktivitet som konkurrerar med skolarbetet, men kanske än viktigare är den en del av deras identitetsbyggande och en central del av tonårstillvaron (Oskarsson, 2011; Schreiner, 2005).

Sammantaget menar vi att svenska elevers större självständighet i vad de väljer att göra eller inte göra ger tydliga utslag i resultaten i årskurs 8. En betydande andel av de uppgifter som vi bedömt vara intressanta för eleverna ingår i meningsfulla sammanhang och anknyter till elevernas erfarenheter. De svenska resultaten på sådana uppgifter är i det internationella perspektivet utmärkta och långt över det genomsnittliga resultatet i jämförelseländerna.

\section{Slutsatser}

Det goda svenska resultatet i årskurs 4 förklaras av att en stor andel av uppgifterna är kopplade till ett sammanhang och till elevernas vardag. Att en låg andel av uppgifterna i årskurs 8 beskriver ett intressant sammanhang eller knyter an till elevernas vardag bidrar till det mindre goda resultatet där. Den svaga kunskapsutvecklingen mellan årskurs 4 och årskurs 8 som TIMSS indikerar tyder på att den formaliserade NO-undervisningen som bedrivs i skolan inte når fram till eleverna utan att det behövs en tydligare anknytning till elevernas intressen och erfarenheter. Ungdomar efterfrågar kunskaper som anknyter till deras egna erfarenheter och deras funderingar om framtiden för dem själva och för världen i stort. Frågor om träning, hälsa och framtida utmaningar har både personlig och samhällelig relevans och ligger dessutom nära den vetenskapliga forskningsfronten. Om NO-undervisningen blir bättre på att knyta an till och utgå från denna typ av frågor kan också ämnena bli mer relevanta för eleverna och NO-undervisningen kan göras mer intressant. Ett ökat intresse och ökat engagemang från eleverna ger också förutsättningar att förbättra kunskapsutvecklingen i NO-ämnena. 


\section{REFERENSER}

Andrée, M. (Ed.). (2007). Den levda läroplanen: en studie av naturorienterande undervisningspraktiker i grundskolan. Stockholm: HLS Förlag.

Benckert, S., Petterson, S., Aasa, S., Johansson, O., \& Norman, R. (2012). Gruppdiskussioner runt kontextrika problem i fysik - Hur ska problemen utformas? Nordic Studies in Science Education, 1(2), 36-50.

Eklöf, H. (2010). Skill and will: test-taking motivation and assessment quality. Assessment in Education: Principles, Policy \& Practice, 17(4), 345-356. doi: 10.1080/0969594X.2010.516569

Eklöf, H. (2015). Att svara eller inte svara: svenska elevers motivation att genomföra PISA-provet. Stockholm: Skolverket.

Hattie, J. A. C. (2008). Visible learning: a synthesis of over 800 meta-analyses relating to achievement. London : New York: Routledge.

Hedrén, J., \& Jidesjö, A. (2010). Kunskap utan kunskapens användning: En studie av fysikläromedel i grundskolans senare år. Stockholm: Skolinspektionen.

Henriksen, E. K., Dillon, J., \& Ryder, J. (2014). Understanding student participation and choice in science and technology education. Dordrecht: Springer.

Jidesjö, A. (2008). Different content orientations in science and technology among primary and secondary boys and girls in Sweden: Implications for the transition from primary to secondary school. Nordina, 4(2).

Jidesjö, A. (2012). En problematisering av ungdomars intresse för naturvetenskap och teknik i skola och samhälle: innehåll, medierna och utbildningens funktion. Norrköping: Department of Social and Welfare Studies, Linköping University.

Jidesjö, A., \& Oskarsson, M. (2016). Mina erfarenheter utanför skolan: 15 åringar om natur och teknik. (in progress).

Lindahl, B. (2003). Lust att lära naturvetenskap och teknik? En longitudinell studie om vägen till gymnasiet. (Ph D), Göteborg: Acta Universitatis Gothoburgensis.

Martin, M. O., \& Mullis, I. V. S. (2014). Methods and procedures in TIMSS and PIRLS 2011. from http://timss.bc.edu/methods/

Martin, M. O., Mullis, I. V. S., Foy, P., \& Stanco, G. (2012). TIMSS 2011 International Science Report.

Nilsson, P. (2012). Att se helheter i undervisningen : naturvetenskapligt perspektiv. Stockholm: Skolverket.

OECD. (2011). Does Participation in Pre-Primary Education Translate into Better Learning Outcomes at School? PISA in Focus (Vol. 1). Paris: OECD.

OECD. (2013). Pisa 2012 results : ready to learn. Vol. 3, Students' engagement, drive and self-beliefs. Paris: OECD.

OECD. (2014). PISA 2012 Results: What Students Know and Can Do (Volume I, Revised edition, February 2014) [Elektronisk resurs]: OECD Publications Centre.

Orpwood, G. (1998). The logic of advice and deliberation: Making sense of science curriculum talk. In D. A. Roberts \& L. Östman (Eds.), Problems of Meaning in Science Curriculum (pp. 133-149).

Osborne, J., \& Dillon, J. (2010). Science Education in Europe: Critical Reflection. London: Kings College.

Osborne, J., Simon, S., \& Collins, S. (2003). Attitudes towards science: a review of the literature and its implications. International journal of Science Education, 25(9), 1049-1079.

Oskarsson, M. (2011). Viktigt - men inget för mig: ungdomars identitetsbygge och intresse för naturvetenskap. Linköpings universitet, Norrköping.

Park, J., \& Lee, L. (2004). Analysing cognitive or non-cognitive factors involved in the process of physics problem-solving in an everyday context. International journal of Science Education, 26(13), 1577-1595.

Rennie, L. J., \& Parker, L. H. (1996). Placing physics problems in real-life context: Students' reactions and performance. Australian Science Teachers Journal, 42(1), 55.

Schreiner, C. (2005). Exploring a ROSE-garden. Norwegian youth's orientations towards scienceseen as signs of late modernity. University of Oslo, Oslo. 
Sjøberg, S. (2010). Naturvetenskap som allmänbildning: en kritisk ämnesdidaktik. Lund: Studentlitteratur.

Sjøberg, S., \& Schreiner, C. (2010). The ROSE project: An overview and key findings. Oslo: University of Oslo.

Skolinspektionen. (2010). Fysik utan dragningskraft. Stockholm: Skolinspektionen.

Skolinspektionen. (2012). Min blev blå! - Men varför då? Stockholm: Skolinspektionen.

Skolverket. (1996). TIMSS: svenska 13-åringars kunskaper i matematik och naturvetenskap i ett internationellt perspektiv. Stockholm: Statens skolverk.

Skolverket. (2000). Grundskolan : kursplaner och betygskriterier. Stockholm: Statens skolverk :.

Skolverket. (2004). Nationella utvärderingen av grundskolan 2003: sammanfattande huvudrapport. Stockholm: Skolverket.

Skolverket. (2006). Med fokus på matematik och naturvetenskap-en analys av skillnader och likheter mellan internationella jämförande studier och nationella kursplaner Skolverkets aktuella analyser, 1652-2508. Stockholm: Skolverket.

Skolverket. (2007). PISA 2006 15-åringars förmåga att förstå, tolka och reflektera - naturvetenskap, matematik och läsförståelse Stockholm: Fritzes.

Skolverket. (2008a). Grundskolan: kursplaner och betygskriterier: förordning (SKOLFS 2000:135) om kursplaner för grundskolan: Skolverkets föreskrifter (2000:141) om betygskriterier för grundskolans ämnen. Stockholm: Skolverket.

Skolverket. (2008b). Med fokus på matematik och naturvetenskap - En jämförelse mellan TIMSS 2007 för årskurs 4 och de nationella målen för årskurs 5 Skolverkets aktuella analyser 2008 2120. Stockholm: Skolverket.

Skolverket. (2011). Läroplan för grundskolan, förskoleklassen och fritidshemmet 2011. Stockholm: Skolverket.

Skolverket. (2012). TIMSS 2011: svenska grundskoleelevers kunskaper i matematik och naturvetenskap i ett internationellt perspektiv. Stockholm: Skolverket.

Skolverket. (2013). PISA 2012 - 15-åringars kunskaper i matematik, läsförståelse och naturvetenskap. Stockholm: Fritzes.

Skolverket. (2014a). TIMSS 2011. Uppgifter i naturvetenskap, årskurs 4.: Skolverket.

Skolverket. (2014b). TIMSS 2011. Uppgifter i naturvetenskap, årskurs 8.: Skolverket.

Skolverket. (2016). SIRIS, Kvalite och resultat i skolan. Retrieved 31/3, 2016, from siris.skolverket.se

Säljö, R. (1998). Learning inside and outside schools: Discursive practices and sociocultural dynamics. In D. A. Roberts \& L. Östman (Eds.), Problems of Meaning in Science Curriculum (pp. 3953).

Teknikdelegationen. (2010). Vändpunkt Sverige: ett ökat intresse för matematik, naturvetenskap, teknik och IKT. Stockholm: Fritzes.

World Value Survey. (2015). from http://www.iffs.se/world-values-survey/ 